\title{
Molecular identification of the occurrence of magnetotactic bacteria in fresh water sediments (Czech Republic)
}

\author{
Martin Rulík, Prem Prashant Chaudhary \\ Laboratory of Aquatic Microbial Ecology, Department of Ecology and Environmental Sciences, \\ Faculty of Science, Palacky University, Olomouc, Czech Republic.
}

Submitted: August 9, 2013; Approved: June 6, 2014

\begin{abstract}
Magnetotactic bacteria (MTB) are of considerable interest because of their importance in the manufacture of various bioinspired materials. In order to find out the status of magnetotactic bacteria at three different sediment in Czech Republic, samples collected from both standing and running freshwaters were subjected to molecular diversity analysis by using $16 \mathrm{~S} r R N A$ gene approach. Total community DNA from sediment sample was isolated and used for PCR, cloning and sequence analysis. Of the 24 analyzed sequences, six clones are closely related to Magnetobacterium sp. affiliated with the Nitrospira phylum which showed the dominance of Magnetobacterium phylotypes in the sample. This study will provide useful insight about the community structure of MTB in this particular geographical region. However more detailed and specific studies are warranted in order to properly assess the community structure of MTB's in fresh water sediments.
\end{abstract}

Key words: magnetotactic bacteria, sediment, $\mathrm{PCR}$, cloning, phylogeny, $16 \mathrm{~S} r R N A$ gene.

\section{Introduction}

Due to the considerable importance of magnetotactic bacteria (MTB) in the generation or manufacture of bioinspired materials, such as functionalized magnetic nanoparticles and nanotubes, magnetic tapes, printing inks, magnetic targeting of pharmaceutical drugs these bacteria are of interest to the microbiologists worldwide. Their role in cell separation and their application as contrast-enhancement agents in magnetic resonance imaging is also of interest to the biologists (Schuler and Frankel, 1999).These all properties are exhibited by these bacteria because of the presence of magnetosome crystals in them. These magnetosomes are specialized organelles consisting of magnetic iron minerals and because of these magnetosomes they are able to align and swim along with magnetic field lines (Keim et al., 2007). These magnetosomes are comprised of membrane bound nano-sized crystals of magnetic iron mineral, which are arranged in one or multiple chain-like structures that enable the cell to passively align it along the external magnetic fields, a behavior known as 'magnetotaxis' (Blakemore, 1975). It is in combination with chemo- taxis, aerotaxis, and perhaps phototaxis, is thought to direct the swimming of cells toward growth-favoring microoxic zones at the bottom of chemically stratified natural waters (Frankel et al., 2006; Thompson et al., 1994). Earlier magnetosome structure and formation were reviewed by Schüler \& Frankel (1999), Schüler (2002) and by Schüller (2008).

MTB represents a diverse group of bacteria with respect to phylogeny, morphology and physiology (Spring and Schleifer, 1995). Most of the phylogenetic and morphologic diversity of the members of this group have been revealed by metagenomic analysis of 16S rRNA gene of the samples collected from natural environments. Magnetotactic prokaryotes have been affilated to two major bacterial lineages majorly, the Proteobacteria and the newly defined phylum Nitrospira. Common morphotypes include coccoid cells as well as rods, vibrios, and spirilla (Blakemore, 1975, 1982; Flies et al., 2005; Lin et al., 2005; Lin et al., 2008; Simmons et al., 2004; Spring et al., 1994, 1998 and Thornhill et al., 1995). Most known MTB are affiliated with the $\alpha$-proteobacteria type, but magnetosome-like inclusions and magnetic orientation have also been described 
for some representatives of the $\delta$-proteobacteria (DeLong et al., 1993; Kawaguchi et al., 1995; Posfai et al., 2006 and Simmons et al., 2004), $\gamma$-proteobacteria (Simmons et al., 2004) and the Nitrospira phylum (Flies et al., 2005 and Spring et al., 1993). Magnetotactic bacteria are frequently found in freshwater or marine sediments. They are most abundant in the oxic-anoxic transition zone of sediments (Flies et al., 2005) but have also been detected in stratified water columns or soil. Despite their high abundance and ubiquitous occurrence in many marine and freshwater habitats, most MTB's are difficult to isolate and cultivate in the laboratory, probably due to their strict lifestyle that is adapted to complex chemical gradients typically found in stratified sediments. The only available and genuinely described pure cultures of magnetotactic bacteria belongs to the genus Magnetospirillum and lies within the Proteobacteria phylum (Burgess et al., 1993 and Kawaguchi et al., 1992)while coccoid magnetotactic bacteria (Flies et al., 2005) and several other morphotypes including the large magnetotactic rod, Magnetobacterium bavaricum containing up to nearly 103 magnetosome particles per cell (Spring et al., 1992 and 1993) are not yet available in pure culture.

As only few magnetotactic bacteria strains are isolated in pure culture by now so there is worldwide increased in the efforts of finding some new culturable strains that were able to produce the magnetosome nanoparticles. So in the current study an effort has been made to check the diversity of MTB at some localities of Czech Republic with the aim to find out the possibility of some culturable MTB strains in this part of the world. In this brief study, we describe first results obtained by detailed molecular analysis of the three microcosm samples thought to be having the most abundant MTB populations.

\section{Material and Methods}

\section{Study sites characteristics, sampling and setup microcosms}

Samples were collected at a depth of 0.5-1 m from 12 different sites in Czech republic during the year 2007-2008. Selected physiochemical parametrs were measure by using portable multimeter HANNA HI9892 (dissolved oxygen, $\mathrm{pH}$, temperature, redox potential) and in laboratory (Total Nitrogen, Total Phosphorus, $\mathrm{Fe}^{2+}$ ) for both surface and interstitial water. In laboratory wet sediment was sieved and only particles $<1.5 \mathrm{~mm}$ were transferred to glass bottles (0.5-1 L), covered loosely and incubated in these microcosms under room temperature and low-light conditions for several months ( 3 replicates for each sample). Each bottle contained $2 / 3$ of sediment and $1 / 3$ of the overlying water originated from particular locality. This water was periodically added during the incubation. After that time, to check the presence of magnetotactic bacteria in the sediment samples, samples were taken just beneath the water sediment interface and used for enrichment by imposing a magnetic field with a bar magnet or MTB cells were enriched by attaching the south pole of a permanent magnet outside a bottle $1 \mathrm{~cm}$ above the sediment surface. After $3 \mathrm{~h}$ mixture of the water and sediment near the south pole of the magnet was collected with a pipette. MTB from three different habitats were also collected for subsequent molecular analysis because of their abundant MTB populations. Sample (microcosm) B was from a small garden pond located in small spa near Buchlovice-Leopoldov, sample D was taken from an oxbow of the Dyje River near Nové Mlýny reservoirs and sample $\mathrm{S}$ became from a Sitka stream, small 3rd order lowland stream near to Olomouc city.

\section{Nucleic acid extraction, PCR amplification, cloning and sequencing}

Total community DNA was extracted from $0.25 \mathrm{~g}$ of sediment with an PowerSoil ${ }^{\mathrm{TM}}$ DNA Isolation Kit (MoBio, Karlsbad, CA) according to the manufaturer's instructions. Bacterial 16S rRNA gene fragments $(\sim 1500 \mathrm{bp})$ were amplified using PCR with the universal primer pair 27F(AGA GTT TGA TCC TGG CTC AG) and 1492R(AAG GAG GTG ATC CAG CCG CA) (Massol-Deya et al., 1995). The steps in PCR include initial denaturation at $94^{\circ} \mathrm{C}$ for $5 \mathrm{~min}$ and 30 cycles consisting of denaturation at $94^{\circ} \mathrm{C}$ for $1 \mathrm{~min}$, primer annealing at $55^{\circ} \mathrm{C}$ for $1 \mathrm{~min}$, and extension at $72{ }^{\circ} \mathrm{C}$ for $1 \mathrm{~min}$. The final elongation step was extended to $10 \mathrm{~min}$. The resulting $1.5 \mathrm{~kb}$ PCR product was purified and cloned into pCR2.1-TOPO cloning vector and transformed into OneShot ${ }^{\mathrm{D}} \mathrm{DH} 5 \alpha^{\mathrm{TM}}$ TOP10 chemically competent Escherichia coli cells according to the manufacturer's instructions (Invitrogen, Carlsbad, CA). Randomly selected clones were sequenced using an ABI PRISM Big Dye Terminator Cycle-Sequencing Ready Reaction kit (PEApplied Biosystems, Foster, CA) and an automatic sequence analyzer (ABI 3700).

\section{BLAST, CLUSTAL W and phylogenetic analysis}

Sequences obtained after sequencing were aligned by using Clustal W (Thompson et al., 1994). The resulting sequences were compared with the Basic Local Alignment Search Tool (BLAST) in order to find out the sequence homology with the magnetotactic bacteria sequences available in the GenBank database. These sequences along with the orher homology sequences are then subjected to phylogenetic analyses using MEGA software (Kimura, 1980 and Kumar et al., 2004). All partial sequences produced in this study have been deposited in GenBank under accession numbers GQ246749 (sequence B6), GQ246750 (D17), GQ246751 (D28), GQ246752 (D32), GQ246753 (S46) and GQ246754 (D47).

\section{Results and Discussion}

In the present study, occurrence and diversity of magnetotactic bacteria present in the sediment samples col- 
lected from 3 different sites in Czech Republic was characterized by using comparative $16 \mathrm{~S}$ rDNA gene sequence analysis. Out of the total analyzed sequences 38\% showed similarity with the members of the phylum Proteobacteria, while $25 \%$ of the sequences resembles with the members of the phylum Nitrospira. The minor groups included the phyla Acidobacteria (17\%), Chloroflexi (13\%) and Verrucomicrobia (8\%). In the phylum Nitrospira, all of these six phylotypes have showed a very high similarity ( $>98 \%$ based on RDP database) to the known magnetotactic bacteria strains and were used further for phylogenetic analysis. On the basis of the higher abundance of magnetotactic bacteria phylotypes, the sediment sample from locality D (oxbow of the Dyje river) has showed the highest phylogenetic diversity than two remaining samples where only one-one phylotype showed a sequence similarity pattern with known MTB sequence was found. In Figure 1 it has been clearly depicted that all cloned bacterial $16 \mathrm{~S}$ rRNA gene sequences obtained from this study were primarily closely related to Magnetobacterium sp. clones affiliated with the Nitrospira phylum. The closest relatives to the four clones from locality D (D17; D28; D32 and D47) were environmental clones retrieved from sediment of one Chinese reservoir (DQ833491), the Yellow Sea sediment (EU652666) and two Magnetobacterium clones from in situ reactor columns degrading benzene filled with lava granules (EF613377 and EF613379) (Kleinsteuber et al., 2008). Four clones determined in this study seems to be related to each other, nevertheless, the high level of sequence divergence (up to $19 \%$, Table 1) indicate that these cloned sequences could belong to different genera. The clone S46 from the small lowland stream was closest to the Magnetobacterium clone ZZ L1B6 (EF613368) which was also recovered from in situ reactor columns degrading benzene filled with lava granules (Kleinsteuber et al., 2008). Finally, the clone B6 from the locality B (small spa pond) seems to be at least similar to the rest of clones retrieved from Czech sediments and is affiliated closely to clone TDNP USbc97 (Acc. No. FJ516912) retrieved from wetland in Central Spain. Our samples have showed only a limited diversity among hitherto described MTB. Long-term cultivation of sediment samples in the microcosms was recommended to enrich MTB. However, there have been some problems in subsequent purification of MTB by using the capillary racetrack (Wolfe et al., 1987). This step might be led to the differences in MTB diversity between molecular and the racetrack approaches (Lin et al., 2008) In this study, we used only molecular approach based on the community DNA extraction from the microcosm samples, thus no changes in community composition should occur here. Magnetobacterium phylotypes affiliated to the phylum Nitrospira comes out to be the dominant phylotype in the clone library generated from our sediments. Large magnetotactic rod-shaped bacteria tentatively named Candidatus Magnetobacterium bavaricum, described for the first time from freshwater lake sediments in Bavaria (Spring et al., 1993), is frequently found in the sediments of some freshwater lakes. This uncultured magnetotactic bacterium is phylogenetically affiliated to the Nitrospira phylum and was given candidatus status due to its distinctive phenotypic traits (Spring et al., 1993). Candidatus Magnetobacterium bavaricumhas been suggested to be a chemolithoautotroph with an iron-dependent mode of energy conservation (Spring et al., 1993). Besides different positioning of the environmental clones which appears to be the closest relative of our clones as mentioned above recently. In a stable isotope probing experiment with C-13 labeled acetate, Magnetobacterium-like organisms were found to metabolize acetate in a methanogenic sediment (Schwarz et al., 2007). Uncultivated magnetotactic members of the phylum Nitrospira were previously detected in various oligotrophic lakes in Upper Bavaria (Spring et al., 1993) and lake in northern Germany (Flies et al., 2005). The general dominance of MTB clones belonging to the phylum Nitrospira in our sediment samples from Czech Republic and relatively high similarity to Magnetobacterium bavaricum (Figure 1) indicates that the occurrence of MTB belonging to this lineage is not geographically restricted to Germany only. Till now there is only one study focusing on rod-shaped bacterium producing magnetite and greigite within its magnetosomes which has been described from oxic-anoxic transition zone of a semi anaerobic estuarine basin of the Pettaquamscutt River, Rhode Island (Bazylinski et al., 1995). To our knowledge this is the first study providing an evidence that MTB may also reside in the sediments of running waters. Since our long-term study revealed that coupling of anaerobic metabolism and methanogenesis appear to be an important pathway in organic carbon cycling in the Sitka stream sediments (Hlavacova et al., 2005; Rulik et al., 2000 and 2008), one expects that MTB might be also involved in methane dynamics as has been already suggested by Schwarz et al. (2007). On the basis of this study we conclude that all Magnetobacterium phylotype affiliated with phylum Nitrospira is the dominant phylotypes of MTB in freshwater sediments in Czech Republic whereas no culturable strain has been reported in this study. When our effort should face to finding of culturable MTB, it seems that further analyses of sediments from various freshwater bodies are therefore required.

On the basis of the MTB diversity in the present study, we can say that this study provides useful insight on the future research work in studying the MTB in fresh water sediments from different parts of the world. This information adds to our understanding of community structure of MTB in this particular geographical region. It also indicated that further studies are warranted in order to properly assess the effect of change in the geographical locations and climatic conditions, on the community structure of MTB's in fresh water sediments. 


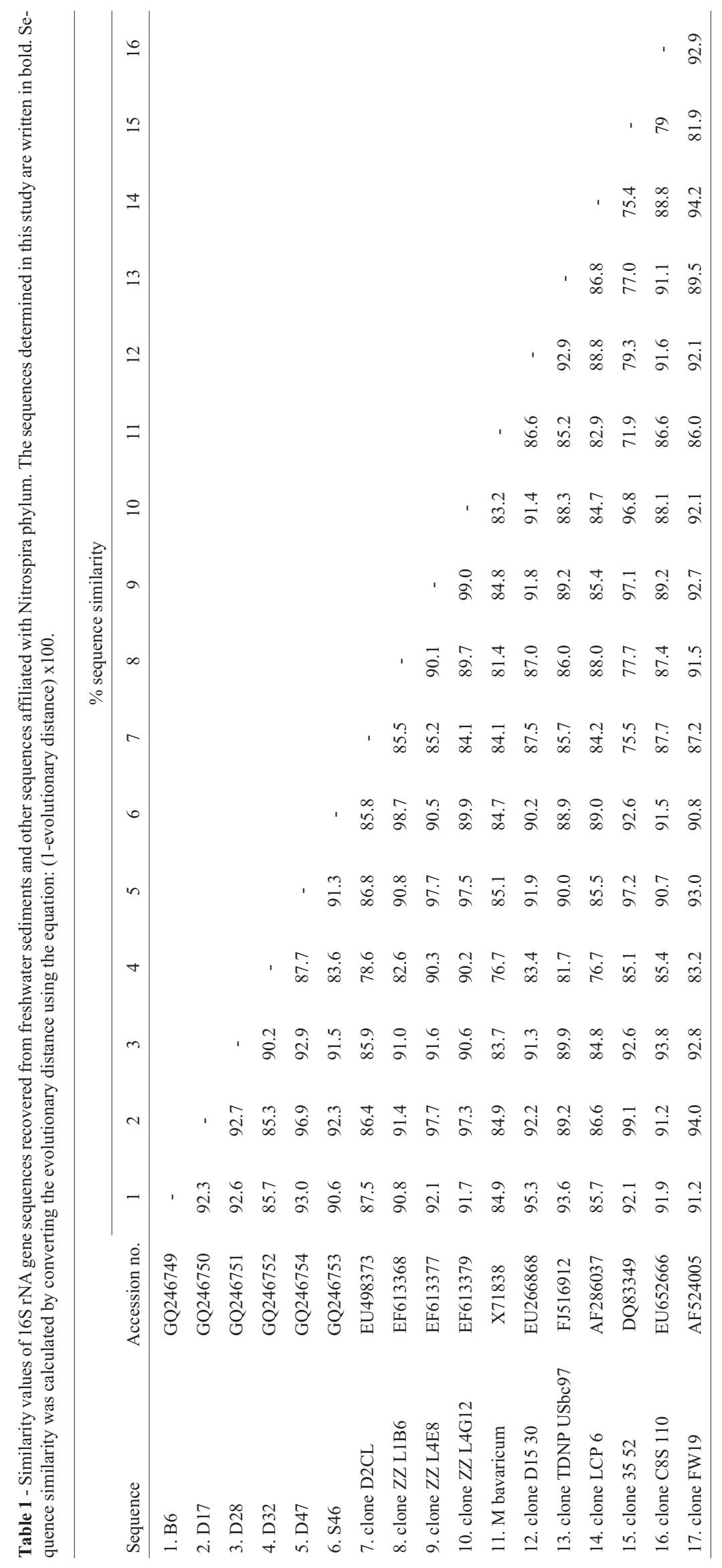




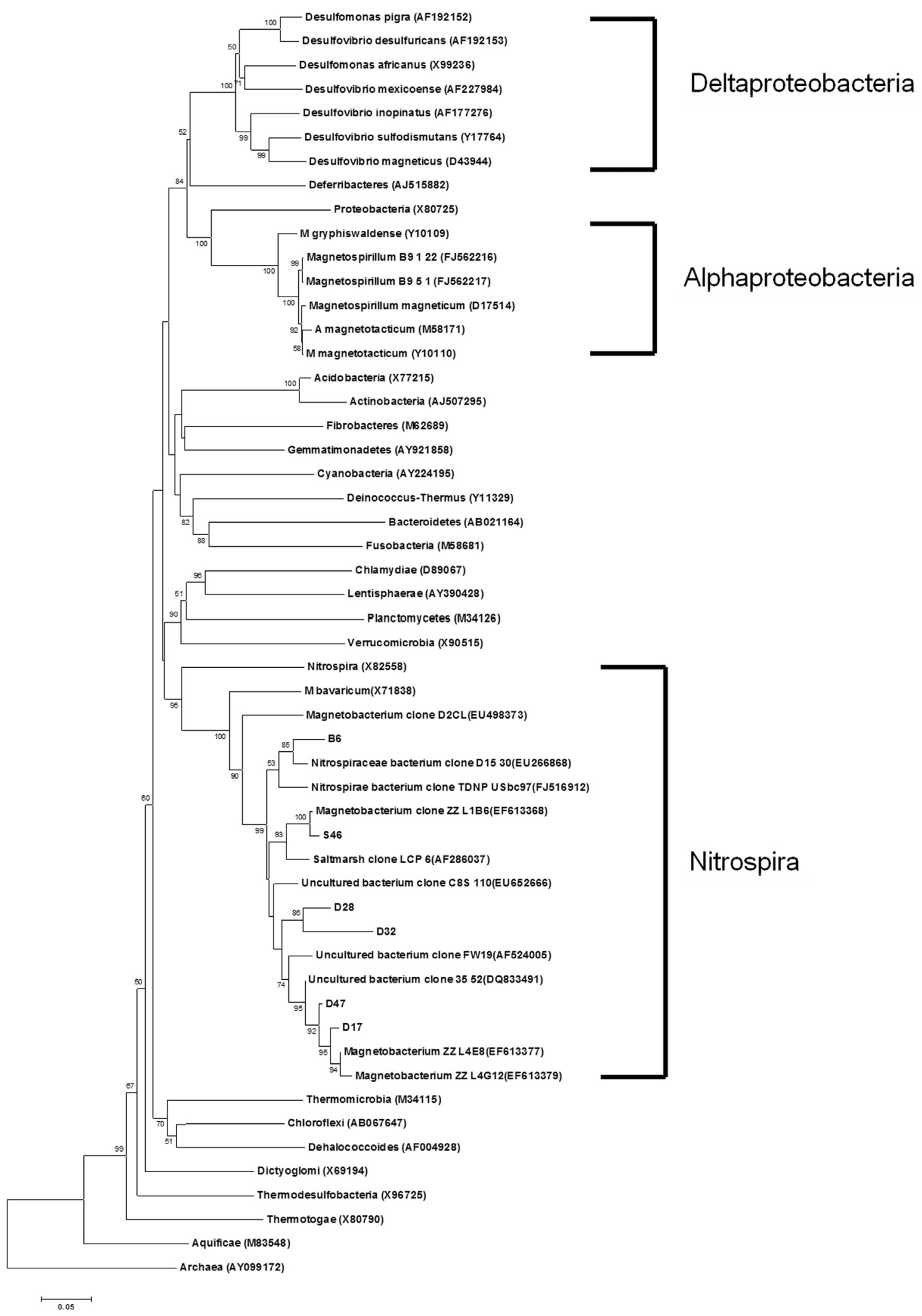

Figure 1 - Phylogenetic positions of magnetotactic bacteria-related 16S rRNA gene sequences recovered from freshwater sediments. The 16S rRNA gene sequences were compared with the most closely related sequences obtained from database (RDP-II), as well as other representatives of related bacterial groups. The phylogenetic distances of each sequence were calculated using the Kimura 2-parameter model and the tree was constructed using the neighbor-joining algorithm. The numbers at the nodes indicate the bootstrap score (as a percentage) and are shown for frequencies at or above the threshold of $50 \%$. The scale bar represents the expected number of changes per nucleotide position. 


\section{Acknowledgments}

We are indebted to the Hankuk University of Foreign Studies for personal grant and position as visiting scholarship (M.R.). We thank Jae Chang Cho for providing access to the laboratory and his kind support for analysis of the samples.Also Sang-Hoon Lee and Do-Hyoung Kim are acknowledged for their assistance during molecular analysis of the samples and phylogenetic tree construction. This work has been supported by the Projects of the Ministry of Education of the Czech Republic (1M6198959201 and MSM6198959218) and by the Project of ASCR (KAN115600801).

\section{References}

Bazylinski DA, Frankel RB, Heywood BR, Mann S, King JW, Donaghay PL, Hanson AK (1995) Controlled biomineralization of magnetite $(\mathrm{F} 3 \mathrm{O} 4)$ and greigite $\left(\mathrm{Fe}_{3} \mathrm{~S}_{4}\right)$ in a magnetotactic bacterium. Appl Environ Microbiol 61:3232-3239.

Blakemore RP (1975) Magnetotactic bacteria. Science 190:377379.

Blakemore RP (1982) Magnetotactic bacteria. Ann Rev Microbiol $36: 217-238$.

Burgess JG, Kawaguchi R, Sakaguchi T, Thornhill RH, Matsunaga (1993) Evolutionary relationships among Magnetospirillum strains inferred from phylogenetic analysis of 16S rDNA sequences. J Bacteriol 175:6689-6694.

DeLong EF, Frankel RB, Bazylinski DA (1993) Multiple evolutionary origins of magnetotaxis in bacteria. Science 259:803-806.

Flies CB, Jonkers HM, de Beer D, Bosselmann K, Bottcher ME, Schuler D (2005) Diversity and vertical distribution of magnetotactic bacteria along chemical gradients in freshwater microcosms. FEMS Micrbiol Ecol 52:185-195.

Flies CB, Peplies J, Schuler D (2005) Combined approach for characterization of uncultivated magnetotactic bacteria from various aquatic environments. Appl Environ Microbiol 71:2723-2731.

Frankel RB, Williams TJ, Bazylinski DA (2006) Magnetoaerotaxis. In: Schuler D (ed) Magnetosomes and Magnetoreception in Bacteria. Volume 3. Springer, Heidelberg, pp 1-24.

Hlavacova E, Rulik M, Cap L (2005) Anaerobic microbial metabolism within hyporheic sediments of a small lowland stream (Sitka stream, Czech Republic). River Res Applic 21:10031011.

Kawaguchi R, Burgess JG, Matsunaga T (1992) Phylogeny and 16S rRNA sequence of Magnetospirillum sp. AMB-1, an aerobic magnetic bacterium. Nucleic Acid Res 20:1140.

Kawaguchi R, Burgess JG, Sakaguchi T, Takeyama H, Thornhill RH, Matsunaga T (1995) Phylogenetic analysis of a novel sulfate-reducing magnetic bacterium, Rs-1, demonstrates its membership of the Deltaproteobacteria. FEMS Microbiol Lett 126:277-282.

Keim CN, Farina M, Lins U(2007) Magnetoglobus, Magnetic Aggregates in Anaerobic Environments. Microbe 2:9:437-445.

Kimura M (1980) A simple method for estimating evolutionary rates of base substitutions through comparative studies of nucleotide sequences. J Mol Ecol 16:111-120.
Kleinsteuber S, Schleinitz KM, Breitfeld J, Harms H, Richnow $220 \mathrm{HH}$, Vogt C (2008) Molecular characterization of bacterial communities mineralizing benzene under sulfate reducing conditions. FEMS Microbiol Ecol 66:143-157.

Kumar S, Tamura K, Nei M (2004) MEGA3: Integrated software for molecular evolutionary genetics analysis and sequence alignment. Brief Bioinform 5:150-163.

Lin W, Tian L, Li J, Pan Y (2008) Does capillary racetrack-base enrichment reflect the diversity of uncultivated magnetotactic cocci in environmental samples? FEMS Microbiol Lett 279:202-206.

Lins U, McCartney MR, Farina M, Frankel RB, Buseck PR (2005) Habits of magnetosome crystals in coccoid magnetotactic bacteria. Appl Environ Microbiol 71:4902-4905.

Massol-Deya, A.A., Odelson, D.A., Hichey, R.P., Tiedje, J.M. (1995) Bacterial community fingerprinting of amplified 16S and 16S-23S ribosomal DNA gene sequences and restriction endonuclease analysis (ARDRA). In: Molecular Microbial Ecology Manual. A.D.L. Akkermans, J.D. van Elsas, F.J. de Bruijn (eds) Kluwer Academic, Dordrecht, pp. 3.3.2-1, 3.3.2-8.

Posfai M, Arato B, Schuler D, Flies C, Bazylinski DA, Moskowitz BM, Frankel RB (2006) Properties of intracellular magnetite crystals produced by Desulfovibrio magneticus RS-1. Earth Plan Sci Lett 249:444-455.

Rulik M, Cap L, Hlavacova E (2000) Methane in the hyporheic zone of a small lowland stream (Sitka, Czech Republic). Limnologica 30:359-366.

Rulik M, Mach V, Cupalova J, Brablcova L, Buriankova I, Cap L (2008) 240 Running waters as an important source of methane emissions to atmosphere: Preliminary results from the Sitka stream, Czech Republic. J Environ Sci Eng 10:43-52.

Schuler D (2002) The biomineralization of magnetosomes in Magnetospirillum gryphiswaldense. Int Microbiol 5:209214.

Schuler D (2008) Genetics and cell biology of magnetosome formation in magnetotactic bacteria. FEMS Microbiol Rev 32:654-672.

Schuler D, Frankel RB (1999) Bacterial magnetosomes: Microbiology, biomineralization and biotechnological applications. Appl Microbiol Biotechnol 52:464-473.

Schwarz JIK, Lueders T, Eckert W, Conrad R (2007) Identification of acetate-utilizing Bacteria and Archea in methanogenic profundal sediments of Lake Kinneret (Israel) by stable isotope probing of rRNA. Environ Microbiol 9:223-237.

Simmons SL, Edwards KJ (2007) Unexpected diversity in populations of the many 257 celled magnetotactic prokaryote. Environ Microbiol 9:206-215.

Simmons SL, Sievert SM, Frankel RB, Bazylinski DA, Edwards KJ (2004)Spatiotemporal distribution of marine magnetotactic bacteria in a seasonally stratified coastal salt pond. Appl Environ Microbiol 70:6230-6239.

Spring S, Amann R, Ludwig W, Schleifer KH, Petersen N (1992) Phylogenetic diversity and identification of nonculturable magnetotactic bacteria. System Appl Microbiol 15:116-122.

Spring S, Amann R, Ludwig W, Schleifer KH, van-Gemerden H, Petersen N (1993) Dominating role of unusual magnetotactin bacterium in the microaerobic zone of freshwater sediment. Appl Environ Microbiol 59:2397-2403.

Spring S, Amann R, Ludwig W, Schleifer K-H, Schuler D, Poralla K, Petersen N (1994) Phylogenetic analysis of uncultured 
magnetotactic bacteria from the alpha-subclass of Proteobacteria. System Appl Microbiol 17:501-508.

Spring S, Lins U, Amann R, Schleifer KH, Ferreira LCS, Esquivel DMS, Farina M (1998) Phylogenetic affiliation and ultrasctructure of uncultured magnetic bacteria with unusually large magnetosomes. Arch Microbiol 169:136-147.

Spring S, Schleifer KH (1995) Diversity of magnetotactic bacteria. Syst Appl Microbiol 18:147-153.

Spring S, Schulze R, Overmann J, Schleifer KH (2000) Identification and characterization of ecologically significant prokyryotes in the sediment of freshwater lakes: Molecular and cultivation studies. FEMS Microbiol Rev 24:573-590.
Thompson JD, Higgins DG, Gibson TJ (1994). CLUSTAL W: Improving the sensitivity of progressive multiple sequence alignment through sequence weighting, position-specific gap penalties and weight matrix choice. Nucleic Acids Res 22:4673-4680.

Thornhill RH, Burgess JG, Matsunaga T (1995) PCR for detection of indigenous uncultured magnetic cocci in sediment and phylogenetic analysis of amplified 16S ribosomal DNA. Appl Environ Microbiol 61:495-500.

Wolfe RS, Thauer RK, Pfennig N (1987) A "capillary racetrack" method for isolation of magnetotactic bacteria. FEMS Microbiol Ecol 45:31-35.

All the content of the journal, except where otherwise noted, is licensed under a Creative Commons License CC BY-NC. 